\title{
CHALLENGES IN LEARNING ENGLISH AS SECONDARY LANGUAGE
}

\section{TIPPABHOTLA VYOMAKESISRI}

M.A English Literature, Osmania University, Hyderabad, Telangana

\section{ABSTRACT}

English is recognized as most spoken language and used widely for communication. In present generation English language learning has become a necessity. The present paper discusses the importance of English language learning in schools and the skills required to master the language. The paper also throws light on the issues and challenges faced by English language learners

KEYWORDS: Language, Learning, Communication, \& English Language

Received: Oct 20, 2017; Accepted: Nov 10, 2017; Published: Nov 22, 2017; Paper Id.: IJELDEC20174

\section{INTRODUCTION}

India is multi linguistic country and land of diversity. Though Hindi is our national language, English is the language mostly used for communication. Learning English is important as people all over world communicate in English mostly. It is noteworthy that, of five official languages UN has recognizes, English language takes the first position because of its easy access to people across the nations. The other reason may be because almost half of the nations in the world were under the British rule. Hence, all the nations had under British rule had to learn English compulsorily. For others learning English is important to keep pace with modern world and many are influenced by English culture. English has emerged as the most important global language and also evolved be a language of science and technology. English as a Second Language (ESL) help students learn how to speak, read and write English. English as a Second Language is a traditional term for the use or study of the English language by non-native speakers in an English-speaking environment. In many schools English is taught as second language with different approaches to those whose primary language is not English.

\section{Skills in English Language Learning}

The skills required for any person to master a language are Listening, Speaking, Reading and Writing. Oracy includes the Listening, speaking skills and reading skills are known as literacy. Therefore, both oracy and literacy together form linguacy. The first two skills like listening and reading are used as the channels, or receiving information and, skills like speaking and writing are called productive skills.

Listening: is an ability to receive and interpret message accurately. To learn English language, listening skills helps in increasing the vocabulary. Listening also improves the learner's comprehension. Listening is the most important skill, as it is an active process. Listening is complex process as it contains features like stress, rhythm, intonation. Listening involves, receiving the sounds of a language in s systematic manner then constructing the sounds into words. Giving meaning to the words received and also includes the ability to interpret and to comprehend the utterances of the speaker. 
Speaking: It is often connected with listening. This skill can be developed by observation and repetition. Here importance given to pronunciation, intonation and stress. Speaking activity involves, the consciousness of the grammatical and cultural features of the language. The ability to speak error-free sentences and situation-based conversation. It is also important to speak the language correctly, with the right pronunciation and present in a comprehensible way

Reading: It includes translating the printed word into sound and derives meaning from the text. Reading is cognitive process as it decoding of symbols in the text. Reading means comprehend written material. Practice is the only way of comprehending written material. Reading involves interaction with the text, where learner decodes and constructs the meaning.

Writing: Of all the skills in language learning writing is the most difficult one. The learner should have awareness of letters and grammar. Writing is a process of conveying thoughts through written symbols. It involves ability to shape letters, convert thought into letters, writing without grammatical errors and finally ability to present the thoughts in comprehensive way.

\section{Challenges in Learning English Language}

The five biggest problems in learning English language are:

\section{Grammar}

It is essential for effective communication and is important in learning English language. When correct usage of grammar in English language learning give intended meaning while its improper usage creates utter confusion and changes completely the meaning of the sentences. Therefore it can be said that English grammar is complex and has to be used logically. English grammar includes learning of theories, rules and regulation which can be mastered only through practical application. Usage of grammar in English is very important as it incorrect usage creates confusion and comprehension becomes difficult.

\section{Vocabulary}

English has one of the biggest vocabularies of all languages. Vocabulary difficulties arise when the complexity of word knowledge is much more than the dictionary definition. Lack of understanding the grammar and incorrect pronunciation also leads to difficulties in vocabulary.

\section{Slang}

Is type of languages consists of words and phrases that are considered to be very informal. It is typically restricted to one particular group.

\section{Pronunciation}

Is result of producing speech which includes intonations, articulation, stress. Many students learning English as second language have problems in pronouncing the words correctly. A student's native language determines, for the most part, the degree of difficulty and the types of difficulties students will have

\section{CONCLUSIONS}

English has become a main subject of competency and a pivotal in the education system. English is considered as 
the second language in every school. It is difficult for the students to understand the English language. Some of specific challenges can be unfamiliar vocabulary, grammar, sentence structure and unfamiliarity with connotative and denotative meanings of words. English language Teacher can create lot of activities for improving the listening, reading and comprehension skills in class everyday for student language development and overcome the challenges faced in learning English.

\section{REFERENCES}

1. Agnihotri, R. K. and Khanna, A. L. (eds.). Problematizing English in India, New D elhi: Sage Publications, 1997.

2. Allen, Virginia French, (ed.). On Teaching English to Speakers o $f$ other Languages, Series I, Papers Read at the TESOL Conference Tucson, Arizona, May 8-9, 1964. Champaign, Illinois: National Council of Teachers of English, 1964.

3. French, F.G., (1963) Teaching English as an International Language, London: Oxford University Press.

4. Ghosh RN (1977) et ai. Introduction to English Language Teacliing, Vol.3 (Methods at the College Level), (London: Oxford University Press, 1977), p.26.

5. Meganathan Rama, (2009), a paper on 'English Language Education in Rural Schools of India : The situation, the policy and the curriculum', www.britishcouncil.org P.4

6. Verghese, C. Paul, (1989) First reprint (1990) 'Teaching English as a Second Language', New Delhi: Sterling Publishers, P.1 
